\title{
PENGARUH FAKTOR FUNDAMENTAL TERHADAP HARGA SAHAM SYARIAH DI JAKARTA ISLAMIC INDEX SEKTOR PROPERTI DAN REAL ESTATE
}

\author{
Sufyati HS ${ }^{1}$ \\ Annisa Febria Rachmawati ${ }^{2}$ \\ ${ }^{1,2}$ Fakultas Ekonomi dan Bisnis Universitas Nasional
}

Email: sufyati.yusuf@gmail.com ${ }^{1}$, annisafebria60@gmail.com ${ }^{2}$

\begin{abstract}
ABSTRAK
Penelitian ini bertujuan untuk menganalisis pengaruh Return on Asset (ROA), Debt to Equity Ratio (DER), Price Earning Ratio (PER), dan Price to Book Value (PBV) terhadap harga saham syariah di Jakarta Islamic Index (JII) sektor properti dan real estate. Data yang digunakan dalam penelitian ini adalah data sekunder dalam bentuk time series yang diperoleh dari laporan keuangan perusahaan yang bersangkutan. Dengan menggunakan metode analisis regresi linier berganda, hasil penelitian menunjukkan bahwa ROA dan PER tidak berpengaruh signifikan terhadap harga saham, DER berpengaruh negatif dan signifikan terhadap harga saham, dan PBV berpengaruh positif dan signifikan terhadap harga saham.
\end{abstract}

Kata kunci: $\quad$ Return on Asset (ROA), Debt to Equity Ratio (DER), Price Earning Ratio (PER), Price to Book Value (PBV), harga saham

\section{ABSTRACT}

This study aims to analyze the effect of Return on Asset (ROA), Debt to Equity Ratio (DER), Price Earning Ratio (PER), and Price to Book Value (PBV) on sharia stock price in Jakarta Islamic index (JII) of property and real estate sector. The data used in this study is secondary data in the form of time series which obtained from the financial reports of the companies. By using linear multiple regression analysis method, results shows that ROA and PER does not have significant effect on the stock price, DER has a negative and significant effect on the stock price, and PBV has a positive and significant effect on the stock price.

Keywords: $\quad$ Return on Asset (ROA), Debt to Equity Ratio (DER), Price Earning Ratio (PER), Price to Book Value (PBV), stock price

\section{PENDAHULUAN}

Di Indonesia, investasi syariah terus mengalami perkembangan dari waktu ke waktu. Salah satu buktinya adalah dengan adanya indeks syariah yang dinamakan Jakarta Islamic Index (JII) yang memuat sekumpulan saham-saham yang memenuhi kriteria investasi dalam syariat Islam. Saham-saham yang terdaftar di JII ini terdiri dari 30 saham terbaik yang sudah lolos uji penyaringan yang dilakukan berdasarkan fatwa yang dikeluarkan oleh Dewan Syariah Nasional. Selain investasi syariah, industri bisnis lainnya yang juga terus mengalami perkembangan adalah industri properti dan real estate. Hal ini 
terjadi karena kenaikan pendapatan masyarakat akibat perkembangan kondisi perekonomian telah mengakibatkan terjadinya kenaikan permintaan yang cukup stabil terhadap produk properti dan real estate. Dengan demikian, perusahaan-perusahaan dengan saham yang memenuhi persyaratan berbasis syariah di sektor properti dan real estate merupakan salah satu perusahaan yang saat ini tengah memiliki daya tarik yang cukup kuat bagi investor.

Berikut ini disajikan tabel pergerakan harga saham properti dan real estate yang terdaftar di JII selama tahun 2013-2017.

Tabel 1. Harga Saham Properti dan Real Estate di JII

Tahun 2013-2017

\begin{tabular}{|c|l|r|c|c|r|r|}
\hline \multirow{2}{*}{ No } & \multicolumn{2}{|c|}{ Perusahaan } & \multicolumn{5}{|c|}{ Harga Saham } \\
\cline { 3 - 7 } & & $\mathbf{2 0 1 3}$ & $\mathbf{2 0 1 4}$ & $\mathbf{2 0 1 5}$ & $\mathbf{2 0 1 6}$ & $\mathbf{2 0 1 7}$ \\
\hline 1 & PT Bumi Serpong Damai Tbk (BSDE) & 1.290 & 1.805 & 1.800 & 1.755 & 1.700 \\
\hline 2 & PT Ciputra Development Tbk (CTRA) & 737 & 1.229 & 1.451 & 1.335 & 1.185 \\
\hline 3 & PT Lippo Karawaci Tbk (LPKR) & 910 & 1.020 & 1.035 & 720 & 488 \\
\hline 4 & PT Summarecon Agung Tbk (SMRA) & 780 & 1.520 & 1.650 & 1.325 & 945 \\
\hline
\end{tabular}

(Sumber: BEI, 2019)

Berdasarkan tabel di atas, harga saham properti dan real estate yang terdaftar di JII justru senantiasa berfluktuasi dari tahun ke tahun. Hampir semua perusahaan mengalami harga saham tertinggi pada tahun 2015 sebelum turun kembali di tahun-tahun berikutnya.

Analisis fundamental adalah suatu metode analisis yang memperhatikan faktorfaktor ekonomi yang dapat mempengaruhi perkembangan suatu perusahaan. Metode fundamental itu sendiri terdiri dari beberapa alat ukur kinerja perusahaan internal, seperti rasio-rasio keuangan yang dapat memberikan pemahaman yang lebih baik terhadap kinerja keuangan perusahaan dan pada akhirnya dapat mempengaruhi harga saham. Beberapa faktor fundamental berupa rasio keuangan yang dapat mempengaruhi harga saham di antaranya adalah Return on Asset (ROA), Debt to Equity Ratio (DER), Price Earning Ratio (PER), dan Price to Book Value (PBV).

Menurut Tambunan (2007), ROA merupakan rasio keuangan yang digunakan untuk menilai kondisi keuangan dari suatu perusahaan dengan menggunakan skala tertentu atau suatu alat untuk menilai apakah seluruh aset yang dimiliki perusahaan sudah dipergunakan semaksimal mungkin untuk mendapatkan keuntungan. Hasil penelitian yang dilakukan oleh Purnamasari, dkk. (2017) serta Wardani dan Andarini (2016) menunjukkan bahwa ROA berpengaruh positif dan signifikan terhadap harga saham. Akan tetapi, hasil 
penelitian yang dilakukan oleh Amrah dan Elwisam (2018) serta Sugiarto dan Khusaini (2014) justru menemukan bahwa ROA tidak berpengaruh signifikan terhadap harga saham.

DER adalah rasio yang membandingkan seberapa besar utang yang ditanggung oleh perusahaan jika dibandingkan dengan ekuitas yang dimilikinya. Beberapa hasil penelitian terdahulu telah menemukan bahwa DER berpengaruh negatif dan signifikan terhadap harga saham, mulai dari Amrah dan Elwisam (2018) hingga Tumandung, dkk. (2017). Akan tetapi, hasil penelitian yang dilakukan oleh Septiany dan Suharyono (2018) serta Manoppo, dkk. (2017) justru menemukan bahwa DER tidak berpengaruh signifikan terhadap harga saham.

PER merupakan perbandingan antara harga saham suatu emiten dengan laba bersih yang dihasilkan oleh emiten tersebut. Adapun yang dimaksud dengan PBV merupakan perbandingan antara harga saham yang ada di pasar dengan nilai buku dari saham tersebut. Berdasarkan hasil penelitian yang dilakukan oleh Septiany dan Suharyono (2018) serta Rahmadewi dan Abundanti (2018), PER memiliki pengaruh yang positif dan signifikan terhadap harga saham. Akan tetapi, Arviana dan Lapoliwa (2013) justru menemukan bahwa PER tidak berpengaruh secara signifikan terhadap harga saham. Adapun variabel PBV terbukti berpengaruh positif dan signifikan terhadap harga saham berdasarkan hasil penelitian yang dilakukan oleh Dewi dan Suaryana (2013) serta Arviana dan Lapoliwa (2013).

Adanya research gap sebagaimana yang telah diuraikan sebelumnya menunjukkan perlunya dilakukannya penelitian untuk menganalisis pengaruh faktor-faktor fundamental yang terdiri dari ROA, DER, PER, dan PBV terhadap harga saham syariah di JII pada sektor properti dan real estate. Penelitian ini nantinya diharapkan dapat memberikan referensi bagi para investor mengenai faktor fundamental mana yang dapat dipergunakan sebagai alat dalam pemilihan saham yang layak untuk diinvestasikan.

\section{TINJAUAN PUSTAKA}

\section{Harga Saham}

Menurut Hartono (2010), harga suatu saham yang terjadi di pasar bursa pada saat tertentu yang ditentukan oleh pelaku pasar dan ditentukan oleh permintaan dan penawaran yang bersangkutan di pasar modal. Sejalan dengan definisi tersebut, Sartono (2008:70) juga menyebutkan bahwa harga saham terbentuk melalui mekanisme permintaan dan penawaran di pasar modal. Apabila suatu saham mengalami kelebihan permintaan, maka 
harganya cenderung mengalami kenaikan. Sebaliknya, apabila suatu saham mengalami kelebihan penawaran, maka harganya justru cenderung mengalami penurunan.

Adapun jenis-jenis harga saham menurut Widoatmodjo (2005) antara lain sebagai berikut.

a. Harga nominal, yakni harga yang tecantum dalam sertifikat saham yang ditetapkan oleh emiten untuk menilai setiap lembar saham yang dikeluarkan.

b. Harga perdana, yakni harga pada waktu saham tersebut dicatat di bursa efek yag biasanya ditetapkan oleh penjamin emisi (underwrite) dan emiten.

c. Harga pasar, yakni harga jual saham dari investor yang satu dengan investor yang lain yang terjadi setelah saham tersebut dicatat di bursa.

d. Harga pembukaan, yakni harga yang diminta oleh penjual atau pembeli pada saat jam bursa dibuka.

e. Harga penutup, yakni harga yang diminta oleh penjual atau pembeli pada saat akhir hari bursa.

f. Harga tertinggi, yakni harga yang paling tinggi yang terjadi pada hari bursa.

g. Harga terendah, yakni harga yang paling rendah yang terjadi pada hari bursa.

h. Harga rata-rata, yakni perataan dari harga tertinggi dan terendah.

\section{Return on Asset (ROA)}

Menurut Tambunan (2007), ROA merupakan rasio keuangan yang digunakan untuk menilai kondisi keuangan dari suatu perusahaan dengan menggunakan skala tertentu atau suatu alat untuk menilai apakah seluruh aset yang dimiliki perusahaan sudah dipergunakan semaksimal mungkin untuk mendapatkan keuntungan. ROA yang positif menunjukkan bahwa dari total aktiva yang dipergunakan untuk beroperasi, perusahaan mampu memberikan laba bagi perusahaan. Sebaliknya, ROA yang negatif menunjukkan bahwa dari total aktiva yang dipergunakan, perusahaan justru mendapatkan kerugian.

Semakin besar ROA, maka semakin besar pula tingkat keuntungan yang dicapai oleh perusahaan tersebut, sehingga semakin baik pula posisi perusahaan dari segi penggunaan assets. Suatu perusahaan yang mempunyai ROA yang tinggi akan berpeluang besar untuk meningkatkan pertumbuhan. Sebaliknya, apabila total aktiva yang digunakan perusahaan tidak memberikan laba, maka perusahaan tersebut akan mengalami kerugian, sehingga akan terhambat pertumbuhannya. 


\section{Debt to Equity Ratio (DER)}

Menurut Darmadji dan Fakhrudin (2012), DER adalah rasio utang yang digunakan untuk mengukur tingkat penggunaan utang terhadap modal sendiri yang dimiliki oleh perusahaan. Rasio ini berguna untuk mengetahui jumlah dana yang disediakan peminjam (kreditor) dengan pemilik perusahaan. Dengan kata lain, rasio ini berfungsi untuk mengetahui setiap rupiah modal sendiri yang dijadikan sebagai jaminan utang (Kasmir, 2012: 157).

DER digunakan untuk mengukur kemampuan perusahaan dalam menutup sebagian atau seluruh utang-utangnya, baik dalam jangka panjang maupun jangka pendek, dengan dana yang berasal dari modal sendiri. Oleh karena itu, semakin rendah nilai DER, maka semakin rendah pula proporsi utang yang digunakan dalam struktur modal perusahaan, sehingga semakin tinggi kemampuan perusahaan untuk membayar seluruh kewajibannya. Sebaliknya, semakin semakin besar nilai DER, maka semakin besar pula proporsi utang yang digunakan dalam struktur modal perusahaan, sehingga semakin rendah kemampuan perusahaan untuk membayar seluruh kewajibannya.

\section{Price Earning Ratio (PER)}

Menurut Hadi (2004), PER adalah sebuah rasio yang mengukur seberapa besar perbandingan antara harga saham perusahaan dengan keuntungan yang akan diperoleh oleh para pemegang saham. Menurut Brigham dan Houston (2012), PER adalah rasio harga per saham terhadap laba per saham yang menunjukkan jumlah yang rela dibayarkan oleh investor untuk setiap dolar laba yang dilaporkan. Menurut Fahmi (2013), PER adalah perbandingan antara market price per share (harga pasar per lembar saham) dengan earning per share (laba per lembar saham) terhadap kenaikan pertumbuhan laba yang diharapkan juga akan mengalami kenaikan.

\section{Price Book Value (PBV)}

Menurut Husnan dan Pudjiasuti (2006), PBV merupakan perbandingan antara harga pasar dan nilai buku saham. Rasio ini mengukur nilai yang diberikan pasar kepada manajemen sebagai sebuah perusahaan yang terus tumbuh. Bagi perusahaan yang berjalan dengan baik, umumnya nilai rasio ini mencapai di atas satu yang menunjukkan bahwa nilai pasar saham lebih besar daripada nilai bukunya. Semakin besar rasio PBV, maka semakin tinggi perusahaan dinilai oleh para investor relatif dibandingkan dengan dana yang telah 
ditanamkan. Sebaliknya, semakin rendah rasio PBV, maka semakin rendah pula perusahaan dinilai oleh para investor relatif dibandingkan dengan dana yang telah ditanamkan. PBV yang tinggi akan membuat pasar percaya atas prospek perusahaan ke depannya. Hal itu juga yang menjadi keinginan para pemilik perusahaan karena nilai perusahaan yang tinggi akan mengindikasikan kemakmuran pemegang saham.

\section{Keterkaitan Antarvariabel Penelitian}

\section{Keterkaitan antara ROA dan Harga Saham}

Hasil penelitian yang dilakukan oleh Purnamasari, dkk. (2017) serta Wardani dan Andarini (2016) menunjukkan bahwa ROA berpengaruh positif dan signifikan terhadap harga saham. Hal tersebut terjadi karena semakin tinggi nilai ROA, maka berarti semakin efektif perusahaan dalam memanfaatkan asetnya untuk menghasilkan laba bersih, sehingga semakin baik kinerja perusahaan di mata investor. Akibatnya, permintaan terhadap saham dari perusahaan tersebut akan mengalami kenaikan, sehingga harga sahamnya juga akan mengalami kenaikan. Sebaliknya, semakin rendah nilai ROA, maka berarti semakin tidak efektif perusahaan dalam memanfaatkan asetnya untuk menghasilkan laba bersih, sehingga semakin buruk kinerja perusahaan di mata investor. Akibatnya, permintaan terhadap saham dari perusahaan tersebut akan mengalami penurunan, sehingga harga saham tersebut juga akan mengalami penurunan.

$\mathrm{H}_{1}$ : $\quad$ ROA berpengaruh positif dan signifikan terhadap harga saham syariah di JII pada sektor properti dan real estate.

\section{Keterkaitan antara DER dan Harga Saham}

Berdasarkan hasil penelitian yang dilakukan oleh Amrah dan Elwisam (2018) serta Tumandung, dkk. (2017), DER memiliki pengaruh yang negatif dan signifikan terhadap harga saham. Hal tersebut terjadi karena semakin rendah nilai DER, maka berarti semakin rendah pula proporsi utang yang digunakan dalam struktur modal perusahaan, sehingga semakin tinggi kemampuan perusahaan untuk membayar seluruh kewajibannya dan semakin baik pula kinerja perusahaan di mata investor. Akibatnya, permintaan terhadap saham dari perusahaan tersebut akan mengalami kenaikan, sehingga harga sahamnya juga akan mengalami kenaikan. Sebaliknya, semakin besar nilai DER, maka berarti semakin besar pula proporsi utang yang digunakan dalam struktur modal perusahaan, sehingga semakin rendah kemampuan perusahaan untuk membayar seluruh kewajibannya dan 
semakin buruk kinerja perusahaan di mata investor. Akibatnya, permintaan terhadap saham dari perusahaan tersebut akan mengalami penurunan, sehingga harga saham tersebut juga akan mengalami penurunan. Selain itu, nilai DER yang tinggi juga menunjukkan tingginya beban utang (biaya bunga) yang harus ditanggung oleh perusahaan. Beban tersebut akan mengurangi laba perusahaan dan pada akhirnya akan semakin memperburuk penilaian investor terhadap perusahaan.

$\mathrm{H}_{2}$ : DER berpengaruh negatif dan signifikan terhadap harga saham syariah di JII pada sektor properti dan real estate.

\section{Keterkaitan antara PER dan Harga Saham}

Berdasarkan hasil penelitian yang dilakukan oleh Septiany dan Suharyono (2018) serta Rahmadewi dan Abundanti (2018), PER memiliki pengaruh yang positif dan signifikan terhadap harga saham. Hal tersebut terjadi karena semakin tingginya PER yang dimiliki oleh suatu perusahaan menunjukkan semakin besarnya kepercayaan yang dimiliki oleh investor terhadap kinerja perusahaan di masa mendatang. Dengan kata lain, PER yang tinggi ini menunjukkan bahwa pasar mengharapkan pertumbuhan harga saham di masa mendatang. Akibatnya, permintaan terhadap saham dari perusahaan tersebut dapat mengalami kenaikan, sehingga harga sahamnya juga dapat mengalami kenaikan. Sebaliknya, semakin rendahnya PER yang dimiliki oleh suatu perusahaan menunjukkan semakin rendahnya kepercayaan yang dimiliki oleh investor terhadap kinerja perusahaan di masa mendatang. Dengan kata lain, PER yang rendah ini menunjukkan bahwa pasar tidak mengharapkan pertumbuhan terhadap harga saham di masa mendatang. Dengan demikian, permintaan terhadap saham dari perusahaan yang bersangkutan dapat mengalami penurunan, sehingga harga saham tersebut juga dapat mengalami penurunan.

$\mathrm{H}_{3}$ : $\quad$ PER berpengaruh positif dan signifikan terhadap harga saham syariah di JII pada sektor properti dan real estate.

\section{Keterkaitan antara PBV dan Harga Saham}

Hasil penelitian yang dilakukan oleh Dewi dan Suaryana (2013) serta Arviana dan Lapoliwa (2013) menunjukkan bahwa PBV berpengaruh positif dan signifikan terhadap harga saham. Hal ini terjadi karena PBV itu sendiri menggambarkan seberapa besar pasar menghargai nilai buku suatu saham. Besarnya rasio ini menggambarkan kepercayaan pasar akan prospek keuangan perusahaan tersebut (Darmadji dan Fakhrudin, 2012). Oleh karena 
dapat memberikan gambaran mengenai potensi pergerakan harga suatu saham, maka dari gambaran tersebut, rasio ini secara tidak langsung juga dapat memberikan pengaruh terhadap harga saham.

Perusahaan dianggap memiliki nilai tambah dan mampu memberi return yang baik di masa mendatang apabila memiliki nilai PBV yang tinggi (Purnamaningsih dan Wirawati, 2014). Semakin besar rasio PBV, maka semakin tinggi perusahaan dinilai oleh para investor relatif dibandingkan dengan dana yang telah ditanamkan. Akibatnya, permintaan terhadap saham dari perusahaan dapat mengalami kenaikan, sehingga harga sahamnya juga dapat mengalami kenaikan. Sebaliknya, semakin rendah rasio PBV, maka semakin rendah pula perusahaan dinilai oleh para investor relatif dibandingkan dengan dana yang telah ditanamkan. Akibatnya, permintaan terhadap saham dari perusahaan dapat mengalami penurunan, sehingga harga sahamnya juga dapat mengalami penurunan.

$\mathrm{H}_{4}$ : $\quad$ PBV berpengaruh positif dan signifikan terhadap harga saham syariah di JII pada sektor properti dan real estate.

\section{Kerangka Pemikiran}

Berikut ini disajkan gambar kerangka pemikiran yang digunakan dalam penelitian ini.

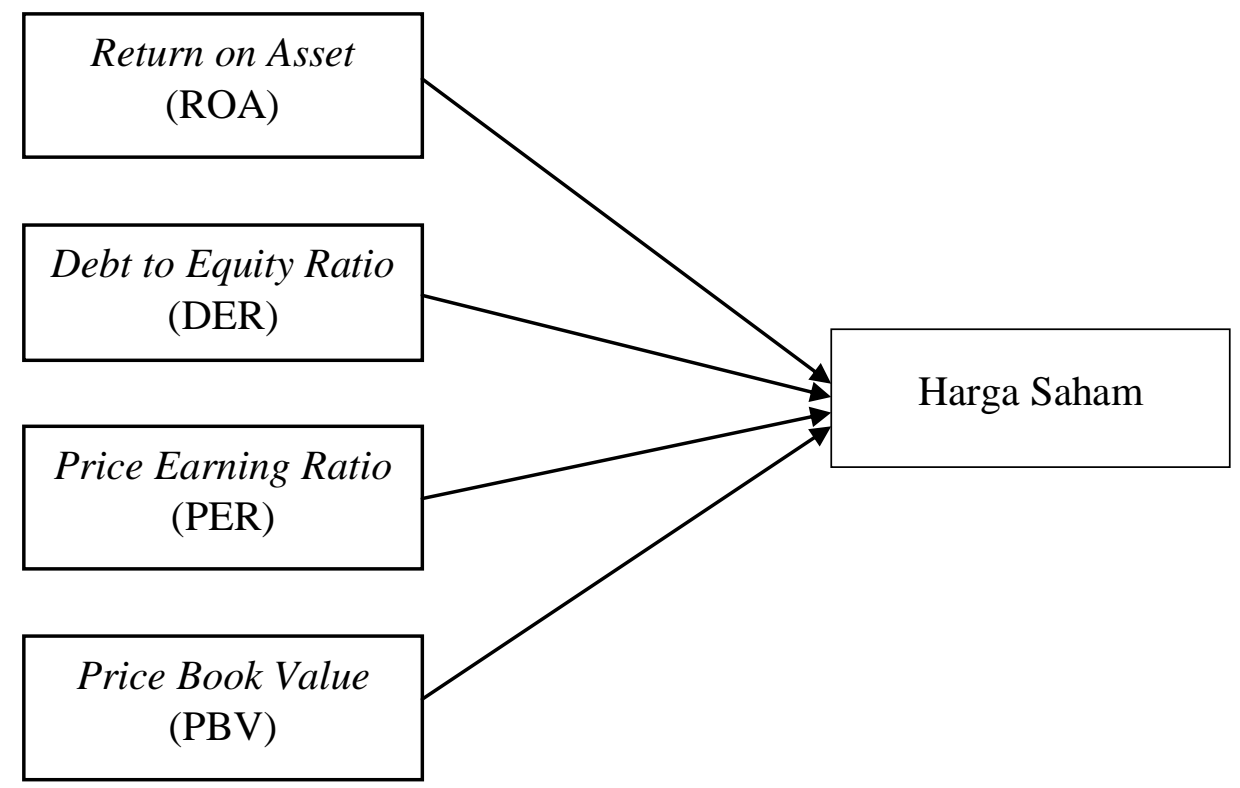

Gambar 1. Kerangka Pemikiran 


\section{METODOLOGI PENELITIAN}

\section{Sumber dan Jenis Data}

Sumber data yang digunakan dalam penelitian ini adalah data sekunder yang diperoleh dari laporan keuangan perusahaan-perusahaan yang bersangkutan selama periode 2013-2017. Adapun jenis data yang digunakan adalah data kuantitatif yang bersifat panel, yakni gabungan antara data time series dan cross section.

\section{Populasi dan Sampel}

Dalam penelitian ini, sampel yang digunakan adalah sampel jenuh karena seluruh data dalam populasi digunakan sebagai sampel. Sampel tersebut diambil dari keempat perusahaan sektor properti dan real estate yang terdaftar di JII selama periode 2013-2017. Dengan demikian, terdapat total 20 observasi yang digunakan dalam penelitian ini.

\section{Definisi Operasional dan Pengukuran Variabel}

\section{Harga Saham}

Dalam penelitian ini, harga saham adalah harga penutupan saham (closing price) tiap perusahaan yang diperoleh pada periode akhir tahun.

\section{Return on Asset (ROA)}

ROA dalam penelitian ini adalah persentase perbandingan antara laba bersih setelah pajak dan total aktiva perusahaan.

$$
\mathrm{ROA}=\frac{\text { Laba bersih setelah pajak }}{\text { Total aktiva }} \times 100 \%
$$

\section{Debt to Equity Ratio (DER)}

DER dalam penelitian ini adalah persentase perbandingan antara total utang dan total ekuitas perusahaan.

$$
\mathrm{DER}=\frac{\text { Total utang }}{\text { Total ekuitas }} \times 100 \%
$$

\section{Price Earning Ratio (PER)}

PER dalam penelitian ini adalah perbandingan antara harga per lembar saham dan laba per lembar saham.

$$
\mathrm{PER}=\frac{\text { Harga saham }}{\text { Laba per saham }}
$$




\section{Price Book Value (PBV)}

PBV dalam penelitian ini adalah perbandingan antara harga pasar per lembar saham dan nilai buku per lembar saham.

$$
\mathrm{PBV}=\frac{\text { Harga per lembar saham }}{\text { Nilai buku per lembar saham }}
$$

\section{Metode Analisis Data}

Metode analisis yang digunakan dalam penelitian ini adalah metode analisis regresi linier berganda (multiple linier regression analyze method) untuk menguji pengaruh variabel ROA, DER, PER, dan PBV terhadap harga saham. Model yang digunakan tersebut disajikan sebagai berikut.

\section{Harga Saham $=a+b_{1}$ ROA $+b_{2}$ DER $+b_{3}$ PER $+b_{4}$ PBV + e}

\section{HASIL DAN PEMBAHASAN}

\section{Hasil Uji Asumsi Klasik}

Dalam penelitian ini, dilakukan uji asumsi klasik yang terdiri dari uji normalitas, uji autokorelasi, uji heteroskedastisitas, dan uji multikolinearitas. Berdasarkan hasil uji normalitas yang dilakukan dengan menggunakan Kolmogorov-Smirnov Test, diperoleh nilai asymp. sig. sebesar 0,200 yang berarti lebih besar daripada 0,05 (0,200>0,05). Hal tersebut menunjukkan bahwa data penelitian terbukti berdistribusi normal.

Dari hasil uji autokorelasi, diperoleh nilai Durbin-Watson sebesar 2,148. Pada tingkat signifikan 5\% dengan jumlah observasi sebanyak 20 dan variabel independen sebanyak $4(\mathrm{k}=4)$, maka diperoleh nilai dL sebesar 0,894 dan dU sebesar 1,828. Dengan demikian, kriteria $\mathrm{dU}<\mathrm{DW}<4$ - dU dapat terpenuhi karena 1,828 $<2,148<2,172$, sehingga model yang digunakan terbukti terbebas dari autokorelasi.

Hasil uji heteroskedastisitas dengan menggunakan Glejser Test menunjukkan bahwa variabel ROA, DER, PER, dan PBV memiliki nilai signifikan masing-masing sebesar 0,$651 ; 0,699 ; 0,490$; dan 0,950. Oleh karena nilai signifikan masing-masing variabel tersebut lebih besar daripada 0,05 , maka model yang digunakan dalam penelitian ini terbukti terbebas dari masalah heteroskedastisitas.

Adapun uji multikolinearitas yang dilakukan menghasilkan nilai VIF variabel ROA, DER, PER, dan PBV masing-masing sebesar 2,255; 2,636; 1,346; dan 2,544. Adapun nilai tolerance untuk masing-masing variabel secara berturut-turut adalah 0,443 ; 
0,$379 ; 0,742$; dan 0,393 . Oleh karena setiap variabel memiliki nilai VIF yang lebih kecil daripada 10 dan nilai tolerance yang lebih besar daripada 0,1 , maka terbukti bahwa tidak terdapat multikolinearitas pada model regresi yang digunakan dalam penelitian ini.

\section{Hasil Uji Regresi Linear Berganda}

Hasil uji regresi linear berganda dengan menggunakan bantuan SPSS 23 dapat dilihat pada tabel berikut ini.

Tabel 2. Hasil Uji Regresi Linear Berganda

\begin{tabular}{|l|r|r|r|r|r|}
\hline \multirow{3}{*}{ Model } & \multicolumn{2}{|c|}{$\begin{array}{c}\text { Unstandardized } \\
\text { Coefficients }\end{array}$} & $\begin{array}{c}\text { Standardized } \\
\text { Coefficients }\end{array}$ & \multirow{2}{*}{$\mathbf{t}$} & \multirow{2}{*}{ Sig. } \\
\cline { 2 - 4 } & \multicolumn{1}{|c|}{ B } & \multicolumn{1}{|c|}{$\begin{array}{c}\text { Std. } \\
\text { Error }\end{array}$} & \multicolumn{1}{|c|}{ Beta } & & \\
\hline (Constant) & $1.661,472$ & 224,230 & & 7,410 & 0,000 \\
ROA & $-13,433$ & 19,893 & $-0,125$ & $-0,675$ & 0,510 \\
DER & $-1.140,585$ & 207,798 & $-1,101$ & $-5,489$ & 0,000 \\
PER & 1,409 & 1,061 & 0,191 & 1,328 & 0,204 \\
PBV & 484,360 & 98,867 & 0,966 & 4,899 & 0,000 \\
\hline
\end{tabular}

(Sumber: Data diolah, 2019)

Berdasarkan hasil uji regresi linear berganda sebagaimana yang disajikan pada tabel di atas, diperoleh model persamaan sebagai berikut.

\section{Harga Saham $=1.661,472-13,433$ ROA $-1.140,585$ DER$$
\text { + 1,409 PER + 484,360 PBV + e }
$$

\section{Hasil Uji Kelayakan Model}

Uji kelayakan model dengan menggunakan uji $\mathrm{F}$ menghasilkan nilai $\mathrm{F}_{\text {hitung }}$ sebesar 12,618 dan nilai signifikan sebesar 0,000. Oleh karena $F_{\text {hitung }}$ terbukti lebih besar daripada $F_{\text {tabel }}(12,618>2,87)$, sementara nilai signifikan lebih kecil daripada taraf signifikan $(0,000$ $<0,05)$, maka model penelitian ini terbukti layak untuk digunakan. Adapun nilai adjusted $R^{2}$ sebesar 0,710 dari uji koefisien determinasi menunjukkan bahwa variabel ROA, DER, PER, dan PBV memberikan kontribusi sebesar $71 \%$ terhadap harga saham perusahaan properti dan real estate di JII, sementara $29 \%$ sisanya dipengaruhi oleh faktor-faktor lain yang tidak dianalisis dalam penelitian ini. 


\section{Hasil Uji Hipotesis}

Berdasarkan tabel 2 yang telah disajikan sebelumnya, dapat dijelaskan hasil pengujian hipotesis sebagai berikut.

1. Variabel ROA mempunyai $t_{\text {hitung }}$ yang lebih kecil daripada $t_{\text {tabel }}(|-0,675|<1,725)$ dengan tingkat signifikan sebesar 0,510 $(0,510>0,05)$, sehingga $\mathrm{H}_{0}$ diterima. Artinya, ROA terbukti tidak memiliki pengaruh yang signifikan terhadap harga saham perusahaan properti dan real estate di JII.

2. Variabel DER mempunyai $t_{\text {hitung }}$ yang lebih besar daripada $t_{\text {tabel }}(|-5,489|>1,725)$ dengan tingkat signifikan sebesar 0,000 $(0,000<0,05)$, sehingga $\mathrm{H}_{0}$ ditolak dan $\mathrm{H}_{\mathrm{a}}$ diterima. Artinya, DER terbukti memiliki pengaruh yang negatif dan signifikan terhadap harga saham perusahaan properti dan real estate di JII.

3. Variabel PER mempunyai $t_{\text {hitung }}$ yang lebih kecil daripada $t_{\text {tabel }}(1,328<1,725)$ dengan tingkat signifikan sebesar 0,204 (0,204 > 0,05), sehingga $\mathrm{H}_{0}$ diterima. Artinya, PER terbukti tidak memiliki pengaruh yang signifikan terhadap harga saham perusahaan properti dan real estate di JII.

4. Variabel PBV mempunyai $t_{\text {hitung }}$ yang lebih besar daripada $t_{\text {tabel }}(4,899>1,725)$ dengan tingkat signifikan sebesar 0,000 $(0,000<0,05)$, sehingga $\mathrm{H}_{0}$ ditolak dan $\mathrm{H}_{\mathrm{a}}$ diterima. Artinya, PBV terbukti memiliki pengaruh yang positif dan signifikan terhadap harga saham perusahaan properti dan real estate di JII.

\section{Pembahasan}

\section{Pengaruh ROA terhadap Harga Saham}

Penelitian ini menunjukkan bahwa ROA tidak memberikan pengaruh yang signifikan terhadap harga saham perusahaan properti dan real estate di JII. Hal tersebut sejalan dengan hasil penelitian yang dilakukan oleh Amrah dan Elwisam (2018) serta Sugiarto dan Khusaini (2014) di sektor lainnya. Hasil ini mencerminkan bahwa perusahaan dengan ROA yang tinggi belum tentu memiliki saham dengan harga yang tinggi pula. Sebaliknya, perusahaan dengan ROA yang rendah belum tentu memiliki saham dengan harga yang rendah pula. Hal tersebut dikarenakan adanya faktor-faktor lain yang dapat memberikan kontribusi yang lebih signifikan dalam mempengaruhi harga saham daripada ROA itu sendiri.

Dalam kasus penelitian ini, DER dan PBV terbukti dapat memberikan kontribusi yang lebih signifikan dalam mempengaruhi harga saham jika dibandingkan dengan 
kontribusi yang diberikan oleh ROA. Hal tersebut menunjukkan bahwa dalam memilih investasi, investor cenderung lebih memperhatikan kemampuan perusahaan dalam membayar utang dan prospeknya di masa mendatang. Hal tersebut terjadi karena jika dibandingkan dengan ROA yang hanya mencerminkan kemampuan perusahaan dalam memperoleh laba dari asetnya, maka DER dan PBV dinilai cenderung lebih fundamental mengingat keduanya dapat turut memproyeksikan keberlanjutan perusahaan ke depannya dengan menggunakan ukuran solvabilitas dan prospek perusahaan.

\section{Pengaruh DER terhadap Harga Saham}

Penelitian ini berhasil membuktikan bahwa DER memiliki pengaruh yang negatif dan signifikan terhadap harga saham perusahaan properti dan real estate di JII. Hal tersebut sejalan dengan temuan Amrah dan Elwisam (2018) serta Tumandung, dkk. (2017). Hal tersebut terjadi karena semakin rendah nilai DER, maka berarti semakin rendah pula proporsi utang yang digunakan dalam struktur modal perusahaan, sehingga semakin tinggi kemampuan perusahaan untuk membayar seluruh kewajibannya dan semakin baik pula kinerja perusahaan di mata investor. Akibatnya, permintaan terhadap saham dari perusahaan tersebut akan mengalami kenaikan, sehingga harga sahamnya juga akan mengalami kenaikan. Sebaliknya, semakin besar nilai DER, maka berarti semakin besar pula proporsi utang yang digunakan dalam struktur modal perusahaan, sehingga semakin rendah kemampuan perusahaan untuk membayar seluruh kewajibannya dan semakin buruk kinerja perusahaan di mata investor. Akibatnya, permintaan terhadap saham dari perusahaan tersebut akan mengalami penurunan, sehingga harga saham tersebut juga akan mengalami penurunan. Selain itu, nilai DER yang tinggi juga menunjukkan tingginya beban utang (biaya bunga) yang harus ditanggung oleh perusahaan. Beban tersebut akan mengurangi laba perusahaan dan pada akhirnya akan semakin memperburuk penilaian investor terhadap perusahaan.

\section{Pengaruh PER terhadap Harga Saham}

Hasil penelitian ini menunjukkan bahwa PER tidak memiliki pengaruh yang signifikan terhadap harga saham perusahaan properti dan real estate di JII. Hal ini sejalan dengan hasil penelitian yang dilakukan oleh Arviana dan Lapoliwa (2013). Meskipun PER dan PBV sama-sama digolongkan sebagai rasio pasar yang dapat menunjukkan prospek perusahaan di masa mendatang, pengaruh keduanya terhadap harga saham justru 
menunjukkan tingkat signifikansi yang berbeda. Dalam hal ini, sementara PER terbukti tidak memiiliki pengaruh yang signifikan terhadap harga saham, PBV justru terbukti memiliki pengaruh yang signifikan secara positif terhadap harga saham. Hal tersebut terjadi karena pengukuran rasio pasar dengan menggunakan nilai buku sebagaimana yang dilakukan pada PBV dinilai dapat lebih akurat dalam menggambarkan prospek perusahaan di masa mendatang mengingat nilai buku itu sendiri cenderung stabil hingga suatu periode tertentu. Adapun pandangan yang kurang meyakini akurasi pengukuran rasio pasar dengan menggunakan laba bersih sebagaimana yang dilakukan pada PER dalam menggambarkan prospek perusahaan di masa mendatang timbul karena laba bersih itu sendiri cenderung mengalami fluktuasi dari waktu ke waktu mengingat data historis laba bahkan belum tentu dapat memprediksi laba di masa mendatang.

\section{Pengaruh PBV terhadap Harga Saham}

Penelitian ini berhasil membuktikan bahwa PER memiliki pengaruh yang positif dan signifikan terhadap harga saham perusahaan properti dan real estate di JII. Hal tersebut sejalan dengan temuan Dewi dan Suaryana (2013) serta Arviana dan Lapoliwa (2013). Hal ini terjadi karena PBV itu sendiri menggambarkan seberapa besar pasar menghargai nilai buku suatu saham. Besarnya rasio ini menggambarkan kepercayaan pasar akan prospek keuangan perusahaan tersebut (Darmadji dan Fakhrudin, 2012). Oleh karena dapat memberikan gambaran mengenai potensi pergerakan harga suatu saham, maka dari gambaran tersebut, rasio ini secara tidak langsung juga dapat memberikan pengaruh terhadap harga saham.

Perusahaan dianggap memiliki nilai tambah dan mampu memberi return yang baik di masa mendatang apabila memiliki nilai PBV yang tinggi (Purnamaningsih dan Wirawati, 2014). Semakin besar rasio PBV, maka semakin tinggi perusahaan dinilai oleh para investor relatif dibandingkan dengan dana yang telah ditanamkan. Akibatnya, permintaan terhadap saham dari perusahaan dapat mengalami kenaikan, sehingga harga sahamnya juga dapat mengalami kenaikan. Sebaliknya, semakin rendah rasio PBV, maka semakin rendah pula perusahaan dinilai oleh para investor relatif dibandingkan dengan dana yang telah ditanamkan. Akibatnya, permintaan terhadap saham dari perusahaan dapat mengalami penurunan, sehingga harga sahamnya juga dapat mengalami penurunan. 


\section{KESIMPULAN DAN SARAN}

\section{Kesimpulan}

Berdasarkan hasil penelitian ini, dapat disimpulkan hal-hal sebagai berikut.

1. ROA tidak berpengaruh secara signifikan terhadap harga saham properti dan real estate yang terdaftar di JII.

2. DER berpengaruh negatif dan signifikan terhadap harga saham properti dan real estate yang terdaftar di JII.

3. PER tidak berpengaruh secara signifikan terhadap harga saham properti dan real estate yang terdaftar di JII.

4. PBV berpengaruh positif dan signifikan terhadap harga saham properti dan real estate yang terdaftar di JII.

\section{Saran}

Berdasarkan kesimpulan di atas, berikut ini disajikan beberapa hal yang dapat dipertimbangkan oleh pihak-pihak yang terkait.

1. Investor disarankan tidak perlu mempertimbangkan ROA dan PER dalam memilih sekuritas di sektor properti dan real estate yang terdaftar di JII mengingat kedua variabel tersebut terbukti tidak berpengaruh signifikan terhadap harga saham.

2. Dalam berinvestasi di sektor properti dan real estate yang terdaftar di JII, investor disarankan untuk memilih sekuritas dari perusahaan yang memiliki DER yang cenderung rendah.

3. Dalam berinvestasi di sektor properti dan real estate yang terdaftar di JII, investor disarankan untuk memilih sekuritas dari perusahaan yang memiliki PBV yang cenderung tinggi atau bahkan diusahakan yang PBV-nya lebih besar daripada 1.

\section{DAFTAR PUSTAKA}

Amrah, R.Y. dan Elwisam. 2018. Pengaruh Current Ratio, Return on Assets, Debt to Equity Ratio dan Total Assets Turnover terhadap Harga Saham pada Perusahaan LQ45 Tahun 2013-2015. Oikonomia: Jurnal Manajemen. 14(1): 46-62.

Arviana, N. dan N. Lapoliwa. 2013. Pengaruh ROA, DER, EPS, PER, dan PBV terhadap Harga Saham: Studi pada Perusahaan Go Public Sektor Properti di BEI Tahun 2009-2011. Ultima Accounting. 5(2): 1-16.

Brigham, E.F. dan J.F. Houston. 2011. Fundamentals of Financial Management. Tenth Edition. Thomson Higher Education. Stamford. Terjemahan A.A Yulianto. 2012. Dasar-dasar Manajemen Keuangan. Edisi Kesepuluh. Salemba Empat. Jakarta. 
Darmadji, T. dan H.M. Fakhrudin. 2012. Pasar Modal di Indonesia. Edisi Ketiga. Salemba Empat. Jakarta.

Dewi, P.D.A. dan I.G.N.A. Suaryana. 2013. Pengaruh EPS, DER, dan PBV terhadap Harga Saham. E-Jurnal Akuntansi Universitas Udayana. 4(1): 215-229.

Fahmi, I. 2013. Analisis Laporan Keuangan. Alfabeta. Bandung. . 2013. Pengantar Manajemen Keuangan. Alfabeta. Bandung.

Hartono, J. 2010. Teori Portofolio dan Analisis Investasi. BPFE UGM. Yogyakarta.

Husnan, S. dan E. Pudjiastuti. 2006. Dasar-Dasar Manajemen Keuangan. Edisi 5. UPP STIM YKPN. Yogyakarta.

Kasmir. 2012. Analisis Laporan Keuangan. Rajagrafindo Persada. Jakarta.

Manoppo, V.C.O., B. Tewal dan A.B.H. Jan. 2017. Pengaruh Current Ratio, DER, ROA dan NPM terhadap Harga Saham pada Perusahaan Food and Beverages yang Terdaftar di BEI Periode 2013-2015. Jurnal EMBA. 5(2): 1813-1822.

Purnamasari, D., E. Nuraina dan E. Astuti. 2017. Pengaruh Capital Adequacy Ratio, Loan to Deposit Ratio dan Return on Asset terhadap Harga Saham Perusahaan Perbankan. The $9^{\text {th }}$ FIPA: Forum Ilmiah Pendidikan Akuntansi. 5(1): 264-277.

Tambunan, A.P. 2007. Menilai Harga Wajar Saham. Elex Media Komputindo. Jakarta.

Rahmadewi, P.W. dan N. Abundanti. 2018. Pengaruh EPS, PER, CR dan ROE terhadap Harga Saham di Bursa Efek Indonesia. E-Jurnal Manajemen Unud. 7(4): 21062133.

Sartono, A. 2008. Manajemen Keuangan: Teori dan Aplikasi. Edisi 4. BPFE. Yogyakarta.

Septiany, A.M. dan Suharyono. 2018. Pengaruh Debt to Equity Ratio, Return on Equity Ratio dan Arus Kas Operasi terhadap Harga Saham pada Subsektor Kontruksi Bangunan dan Subsektor Property yang Terdaftar di BEI Tahun 2011-2015. Oikonomia: Jurnal Manajemen. 14(2): 59-76.

Sudana, I.M. 2011. Manajemen Keuangan Perusahaan. Erlangga. Jakarta.

Sugiarto, R.J.E. dan Khusaini. 2014. Pengaruh DER, DPS, dan ROA terhadap Harga Saham Perusahaan Telekomunikasi yang terdaftar di Bursa Efek Indonesia. Jurnal Ilmu dan Riset Manajemen. 3(9): 1-15.

Sugiyono. 2010. Metode Penelitian Pendidikan (Pendekatan Kuantitatif, Kualitatif, $R \& D)$. Alfabeta. Bandung.

Tumandung, C.O., S.Murni dan D.N. Baramuli. 2017. Analisis Pengaruh Kinerja Keuangan terhadap Harga Saham pada Perusahaan Makanan dan Minuman yang Terdaftar di BEI Periode 2011-2015. Jurnal EMBA. 5(2): 1728-1737. 
Wardani, D.K. dan D.F.T. Andarini. 2016. Pengaruh Kondisi Fundamental, Inflasi dan Suku Bunga Sertifikat Bank Indonesia terhadap Harga Saham: Studi Kasus pada Perusahaan Real Estate dan Property yang Terdaftar di Bursa Efek Indonesia Tahun 2010-2013. Jurnal Akuntansi. 4(2): 77-90.

Widoatmodjo, S. 2005. Cara Sehat Investasi Pasar Modal. Elex Media Komputindo. Jakarta.

https://www.finance.yahoo.com

https://www.idx.co.id 